John M. Murkin MD FRCPC, C. Craig Moldenhauer MD, Carl C. Hug Jr. MD, PH D

\title{
High-dose fentanyl for rapid induction of anaesthesia in patients with coronary artery disease
}

Nine premedicated patients, chronically maintained on beta-adrenergic blocking agents and demonstrating good ventricular function without significant valvular or lefi main coronary artery disease, were investigated to determine their haemodynamic responses to rapid induction of anaesthesia and tracheal intubation during elective coronary artery bypass surgery. Fentanyl $50 \mu \mathrm{g} \cdot \mathrm{kg}^{-1}$ and pancuronium $0.15 \mathrm{mg} \cdot \mathrm{kg}^{-1}$ were administered intravenously over 20 seconds followed by tracheal intubation 90 seconds thereafter. The rapid sequence of anaesthetic induction and tracheal intubation was well tolerated by all patients. Though statistically significant changes were detected in heart rate, pulmonary capillary wedge pressure and systemic vascular resistance, these changes were small and not considered clinically significant and no signs of ischaemia were detected on the ECG. The present study demonstrates that high-dose fentanyl is capable of inducing anaesthesia rapidly and protecting against the haemodynamic changes associated with tracheal intubation.

\section{Key words}

ANAESTHESIA: cardiovascular; INDUCTION: anaesthesia; ANAESTHETICS, INTRAVENOUS: fentanyl

From the Division of Cardiothoracic Anesthesia, Department of Anesthesiology, Emory University School of Medicine, Atlanta, Georgia.

Presented in part at the Annual Meeting of the Canadian Anaesthetists' Society, Winnipeg, Manitoba, June 1984.

Address correspondence to: Dr. J.M. Murkin, Department of Anaesthesia, University Hospital, P.O. Box 5339, Station "A", London, Ontario, Canada N6A 5 A5.
High-dose narcotic anaesthesia, particularly using the synthetic drug fentanyl or one of its congeners, has become a popular anaesthetic technique for cardiac surgery, purportedly because of the greater haemodynamic stability it confers. Because some patients with coronary artery disease may be at increased risk of pulmonary aspiration during the induction of anaesthesia (i.e., full stomach, oesophageal reflux), we investigated the use of highdose fentanyl for rapid induction of anaesthesia.

Recent work utililizing a slow intravenous infusion of fentanyl $8.6 \mu \mathrm{g} \cdot \mathrm{kg}^{-1}$, has demonstrated a significant time lag between peak fentanyl concentration in plasma and maximal changes in the electroencephalograph (EEG). ${ }^{\prime}$ The use of larger doses given rapidly might be expected to speed the onset of fentanyl's actions. We have previously observed unconsciousness and abrupt slowing of the EEG (delta waves) characteristic of fentanyl anaesthesia within 30 seconds of an IV bolus of fentanyl $50 \mu \mathrm{g} \cdot \mathrm{kg}^{-1} .^{2}$ In another clinical study, however, hypertension occurred in response to laryngoscopy and tracheal intubation after a fentanyl dose of $50 \mu \mathrm{g} \cdot \mathrm{kg}^{-1}$ injected in 60 seconds. ${ }^{3}$

The present study was designed to assess the efficacy of fentanyl in rapidly inducing anaesthesia and obtunding haemodynamic responses to intubation.

\section{Methods}

Following institutional approval and after obtaining informed consent, nine patients maintained on chronic beta-adrenergic receptor blocker therapy and scheduled for elective coronary artery bypass (CABG) surgery, were studied. Patients with left 
TABLE I Patient characteristics

\begin{tabular}{|c|c|c|c|c|c|c|c|}
\hline PATIENT & $\begin{array}{l}\text { AGE } \\
\text { \{yr. }\end{array}$ & SEX & $\begin{array}{l}\text { WT. } \\
\text { (kg) }\end{array}$ & $\begin{array}{l}\text { ASSOCIATED } \\
\text { CONDITIONS }\end{array}$ & $\begin{array}{c}\text { MEDICATIONS } \\
\text { (Daily dose in mg) }\end{array}$ & $\begin{array}{l}\text { EJECTION } \\
\text { FRACTION }\end{array}$ & $\begin{array}{c}\text { CABG } \\
\text { (Vessels grathed) }\end{array}$ \\
\hline 1 & 60 & $M$ & 83 & - hypertension & $\begin{array}{l}\text { - propranolol } 120 \\
\text { - topical nitroglycerin } \\
\text { - chlorthalidone } 100\end{array}$ & 0.60 & 4 \\
\hline 2 & 63 & $\mathrm{~F}$ & 93 & $\begin{array}{l}\text { - hypertension } \\
\text { - chronic bronchitis } \\
\text { - obesity } \\
\text { - hiatus hernia }\end{array}$ & $\begin{array}{l}\text { - nadolol } 40 \\
\text { - nifedipine } 30 \\
\text { - topical nitroglycerin } \\
\text { - triamterene } 50 \\
\text { - hydrochlorothiazide } 25 \\
\text { - cimetidine } 900\end{array}$ & 0.65 & 3 \\
\hline 3 & 54 & $M$ & 89 & - hypertension & $\begin{array}{l}\text { - nadolol } 80 \\
\text { - nifedipine } 40 \\
\text { - digoxin } 0.25 \\
\text { - furosemide } 40\end{array}$ & 0.65 & 3 \\
\hline 4 & 58 & $M$ & 86 & - peptic ulcer & $\begin{array}{l}\text { - timolol } 20 \\
\text { - procainamide } 1000\end{array}$ & 0.65 & 5 \\
\hline 5 & 47 & $\mathrm{~F}$ & 79 & - hypertension & $\begin{array}{l}\text { - propranolol } 160 \\
\text { - nifedipine } 60 \\
\text { - topical nitroglycerin } \\
\text { - triamterene } 50 \\
\text { - hydrochlorothiazide } 25\end{array}$ & 0.50 & 3 \\
\hline 6 & 67 & $M$ & 84 & - hypertension & $\begin{array}{l}\text { - atenolal } 50 \\
\text { - diltiazem } 240 \\
\text { - isosorbide dinitrate } 40 \\
\text { - topical nitroglycerin }\end{array}$ & 0.65 & 3 \\
\hline 7 & 44 & $M$ & 99 & $\begin{array}{l}\text { - obesity } \\
\text { - hiatus hernia }\end{array}$ & $\begin{array}{l}\text { - propranolol } 80 \\
\text { - diltiazem } 240 \\
\text { - topical nitroglycerin }\end{array}$ & 0.65 & 2 \\
\hline 8 & 55 & $M$ & 97 & $\begin{array}{l}\text { - obesity } \\
\text { - bronchiectasis }\end{array}$ & - propranalol 80 & 0.60 & 4 \\
\hline 9 & 50 & $M$ & 70 & - none & - propranolol 80 & 0.55 & 1 \\
\hline
\end{tabular}

main coronary artery disease, an ejection fraction less than 0.5 , or significant valvular heart disease were excluded. All patients displayed sinus rhythm on their electrocardiogram (ECG). On the morning of surgery, all patients received their usual antianginal medications, including beta-blockers, one to four hours preoperatively (Table I). Premedication consisting of morphine $0.15 \mathrm{mg} \cdot \mathrm{kg}^{-1}$ and scopolamine $5 \mu \mathrm{g} \cdot \mathrm{kg}^{-1} \mathrm{IM}$ and diazepam 0.15 $\mathrm{mg} \cdot \mathrm{kg}^{-1}$ PO was administered 90 minutes prior to surgery. A radial artery cannula, two large bore IV cannulae, and a pulmonary artery catheter were inserted percutaneously under local anaesthesia and prior to induction of general anaesthesia. ECG leads II and V5 were displayed continuously on an oscilloscope throughout the study period and were simultaneously recorded, along with systemic and pulmonary artery pressures, on a calibrated Hewlett-Packard strip chart recorder running continuously throughout the study period at a speed of $5 \mathrm{~mm} / \mathrm{sec}$. Following administration of lactated Ringer's solution to produce a pulmonary capillary wedge pressure (PCWP) of at least $10 \mathrm{mmHg}$ and after five minutes with the patient breathing 100 per cent oxygen by mask, fentanyl $50 \mu \mathrm{g} \cdot \mathrm{kg}^{-1}$ and pancuronium $0.15 \mathrm{mg} \cdot \mathrm{kg}^{-1}$ were simultaneously administered intravenously over 20 seconds.

Heart rate (HR), cardiac output $(\mathrm{CO})$, mean arterial (MAP), central venous (CVP) and pulmonary arterial (PAP) and pulmonary capillary wedge pressures (PCWP) were obtained and cardiac index (CI) and systemic vascular resistance (SVR) were calculated. Control (C) haemodynamic measurements were obtained prior to oxygenation and $1 \mathrm{~min}, 3 \mathrm{~min}$, and $5 \mathrm{~min}$ following fentanyl administration. Patients were intubated 90 seconds after the completion of fentanyl administration. Hypertension (increase in MAP $25 \%>\mathrm{C}$ ) was treated with thiopentone $100 \mathrm{mg}$, and hypotension (decrease in MAP $25 \%<$ C) was treated with ephedrine $5 \mathrm{mg}$ intravenously. After the study, anaesthesia was maintained at the anaesthetist's discretion and included diazepam, fentanyl, and enflurane or isoflurane. Results are presented as the mean \pm SEM. Data were analyzed by two-way analysis of variance; $p<0.05$ was considered significant. 
TABLE II Haemodynamic variables before and after fentanyl*

\begin{tabular}{|c|c|c|c|c|c|}
\hline & $\begin{array}{l}\text { HR@ } \\
\text { bpm } \\
\text { (range) }\end{array}$ & $\begin{array}{l}C l \\
L \cdot \min ^{-1} \cdot m^{-2} \\
\text { (range) }\end{array}$ & $\begin{array}{l}\text { MAP } \\
\text { mmHg } \\
\text { (range) }\end{array}$ & $\begin{array}{l}\text { SVRT } \\
\text { dyne.sec } \cdot \mathrm{cm}^{-5} \\
\text { (range) }\end{array}$ & $\begin{array}{l}P C W P \$ \\
m m H g \\
\text { (range) }\end{array}$ \\
\hline Control & $\begin{array}{r}57 \pm 3 \\
(45-76)\end{array}$ & $\begin{array}{l}2.6 \pm 0.2 \\
(1.7-3.5)\end{array}$ & $\begin{array}{r}85 \pm 3 \\
(68-95)\end{array}$ & $\begin{array}{l}1209 \pm 78 \\
(903-1511)\end{array}$ & $\begin{array}{r}12 \pm 1 \\
(10-16)\end{array}$ \\
\hline $1 \mathrm{~min}$ & $\begin{array}{r}65 \pm 3 \\
(50-78)\end{array}$ & $\begin{array}{l}2.8 \pm 0.2 \\
(1.8-4.2)\end{array}$ & $\begin{array}{c}79 \pm 4 \\
(63-103)\end{array}$ & $\begin{array}{l}1062 \pm 88 \\
(706-1455)\end{array}$ & $\begin{array}{l}12 \pm 1 \\
(9-14)\end{array}$ \\
\hline $1.5 \mathrm{~min}$ & & (Intubation) & & & \\
\hline $3 \min$ & $\begin{array}{r}66 \pm 3 \\
(55-81)\end{array}$ & $\begin{array}{c}2.9 \pm 0.2 \\
(1.9-3.8)\end{array}$ & $\begin{array}{r}78 \pm 3 \\
(60-92)\end{array}$ & $\begin{array}{l}1021 \pm 86 \\
(723-1400)\end{array}$ & $\begin{array}{l}11 \pm 1 \\
(8-14)\end{array}$ \\
\hline $5 \min$ & $\begin{array}{r}66 \pm 3 \\
(55-84)\end{array}$ & $\begin{array}{l}2.9 \pm 0.2 \\
(2.0-3.6)\end{array}$ & $\begin{array}{r}77 \pm 4 \\
(56-90)\end{array}$ & $\begin{array}{c}999 \pm 72 \\
(789-1470)\end{array}$ & $\begin{array}{l}10 \pm 1 \\
(7-13)\end{array}$ \\
\hline
\end{tabular}

*Values are means \pm SEM. Data analyzed by two-way analysis of variance. $t_{p}<0.05$;

$\S_{p}<0.01$

\section{Results}

In all patients, loss of responsiveness to voice occurred at $30 \pm 15$ seconds following fentanyl administration. Laryngoscopy and intubation commenced 90 seconds following completion of fentanyl administration and was accomplished within 30 seconds. Intubating conditions were considered good. No patient had recall of intubation or any intraoperative event.

There was no statistically significant change in the mean group values for $\mathrm{Cl}$ or MAP, but two patients (patient 2 and patient 5) had a transient 30 per cent decrease in MAP. The systolic blood pressure remained greater than $95 \mathrm{mmHg}$ in both patients and treatment was not required. Statistically significant changes were found in HR, PCWP, and SVR (Table II). In three patients HR increased by more than 30 per cent from control (patient 1: 64 to 84 ; patient $4: 45$ to 57 ; patient $7: 47$ to 71 ) but no patient developed a HR greater than 85 or less than 50 and no arrhythmias or ST-T wave changes occurred during the study period. The SVR remained within $700-1500$ dyne $\cdot \mathrm{sec} \cdot \mathrm{cm}^{-5}$ in all patients, and in two patients (patient 2 and patient 8 ) the $\mathrm{CI}$ decreased by less than 15 per cent from the control values. None of these changes were felt to be clinically important, and they did not require any intervention.

\section{Discussion}

A $50 \mu \mathrm{g} \cdot \mathrm{kg}^{-1}$ dose of fentanyl administered intravenously in 20 seconds has previously been shown to reliably produce plasma fentanyl concentrations in excess of $20 \mathrm{ng} \cdot \mathrm{ml}^{-1}$ for up to seven to eight minutes and results in the rapid production of unconsciousness (i.e., loss of response to commands) and EEG slowing. ${ }^{2}$ Patients were not intubated during that study, however, thus their haemodynamic responses to the stresses of laryngoscopy and intubation were not assessed.

By administering fentanyl as a slow infusion, Scott et al. ' demonstrated a delay in the onset of fentanyl's effect on the EEG. In contrast, with rapid administration of high doses of fentanyl, anaesthetic conditions were produced within 90 seconds in our patients. Becase of its high lipid solubility, if tissue perfusion remains constant then diffusion of fentanyl into the brain is primarily determined by the plasma/tissue concentration gradient. ${ }^{4}$ The rapid production of transiently high plasma fentanyl concentrations (in excess of $1200 \mathrm{ng} \cdot \mathrm{ml}^{-1}$ ) that is achieved with the high-dose bolus technique, ${ }^{2}$ produces a very large concentration gradient for diffusion of fentanyl into the brain. These high plasma concentrations produce a rapid accumulation of fentanyl in brain and cause a rapid onset of anaesthesia. ${ }^{1,5}$ Maximum brain concentrations have been reported to occur in rabbits within 30 seconds after intravenous injection of fentanyl $20 \mu \mathrm{g} \cdot \mathrm{kg}^{-1}{ }^{6}$

All patients in this study tolerated the rapid sequence of anaesthetic induction and tracheal intubation without problem. Though not describing a rapid sequence induction technique, Sprigge $e t a l$. 
observed similar haemodynamic stability during induction and intubation in a group of patients receiving fentanyl $50 \mu \mathrm{g} \cdot \mathrm{kg}^{-1}$ and pancuronium $0.15 \mathrm{mg} \cdot \mathrm{kg}^{-1}$ for induction of anaesthesia. ${ }^{7}$ Though blood pressure, PCWP, CI and SVR did not change significantly, they did observe a statistically significant increase in heart rate of approximately 15 per cent following induction, and 25 per cent following intubation, slightly greater than the increases in HR of 10 and 15 per cent observed in our study at similar times. This study differed from ours however in that their rate of administration of fentanyl was $1 \mathrm{mg} \cdot \mathrm{min}^{-1}$ versus our rate of $50 \mu \mathrm{g} \cdot \mathrm{kg}^{-1}$ over 20 seconds. Similarly, in their study 1 to $2 \mathrm{mg}$ of pancuronium preceded the administration of fentanyl and was followed by the remainder of the $0.15 \mathrm{mg} \cdot \mathrm{kg}^{-1}$ total dose of pancuronium upon loss of consciousness, whereas in our study the total dosages of both fentanyl and pancuronium were administered concomitantly over 20 seconds. The patients of Sprigge et al. also had a slightly higher control heart rate of $62 \pm 2$ versus 57 \pm 3 in our patients, presumably because only eight of ten of their patients were chronically maintained on beta-adrenergic receptor blockers. The higher incidence of hypertension observed by Kentor et $a l{ }^{3}$ may be due to several factors: slower fentanyl administration producing lower peak fentanyl concentrations in plasma and brain, delayed administration of relaxants leading to hypercarbia with secondary sympatho-adrenal stimulation, possibly absent or inadequate beta-adrenergic receptor blockade and a greater interval between fentanyl administration and intubation (approximately 6.5 min) allowing fentanyl concentrations to decline. Higher plasma fentanyl concentrations generally produce greater haemodynamic stability ${ }^{7}$ and fentanyl appears to more directly antagonize the chronotropic effects of pancuronium when the two drugs are administered concomitantly. In A.S.A. physical status class I-II patients who had not received preoperative beta-adrenergic receptor blockers and who were anaesthetized with a combination of meperidine-diazepam, administration of pancuronium in a dosage of twice its $\mathrm{ED}_{95}$ produced a mean increase in heart rate of greater than 20 per cent. ${ }^{8} \mathrm{~A}$ different group of investigators, however, found this same dose of pancuronium when utilized with fentanyl in a balanced anaesthetic technique produced a heart rate rise of more than 20 per cent above control values in only two of ten patients and it was promptly reversed with additional fentanyl $100-150 \mu \mathrm{g} .9$

Because of the propensity of narcotics, particularly fentanyl, to produce a centrally mediated reduction in heart rate, ${ }^{10}$ we elected to use pancuronium, a muscle relaxant with vagolytic properties," in a dosage (twice the $\mathrm{ED}_{95}$ ) shown to reliably produce rapid onset of muscular paralysis, ${ }^{8,9}$ in order to antagonize the fentanyl-induced vagotonia. Succinylcholine was avoided as it would not prevent and might even exacerbate the bradycardia that is produced when fentanyl is administered rapidly and in a large dosage to these patients with a high degree of pre-existing betareceptor blockade. ${ }^{12}$ No difference in the heart rate response to an $\mathrm{ED}_{95}$ dosage of either pancuronium or a pancuronium-metocurine combination was found when these drugs were administered to patients receiving chronic propranolol therapy and undergoing CABG surgery. ${ }^{13}$ Patients receiving the pancuronium-metocurine combination did have a lower MAP and SVR compared to the pancuronium treated group however, and it was this potential for hypotension that mitigated against using this combination of relaxants for rapid administration in our study. It has also been demonstrated that occurrence of maximum neuromuscular blockade is more rapid when using an intubating dosage of pancuronium (twice the $\mathrm{ED}_{95}$ ) as opposed to a comparable dosage of the pancuronium-metocurine combination; 1.8 verus 2.6 minutes, respectively. ${ }^{8}$

The patients in the current study were all maintained on chronic beta-adrenergic receptor blocker therapy and received their last dose orally between one and four hours prior to the induction of anaesthesia. We believe the continuation of this therapy contributed significantly to their haemodynamic stability during induction of anaesthesia. We have previously observed hyperdynamic responses to the rapid induction and intubation technique described here in two other patients who were not receiving beta-blockers preoperatively. Differences in the haemodynamic responses of patients chronically maintained with beta-adrenergic receptor blocker therapy and those not receiving this therapy have been previously reported. ${ }^{14,15}$ In a group of patients undergoing CABG surgery, Stanley et al. observed a lesser incidence of intraoperative hypertension and the dosage require- 
ments for narcotic anaesthesia were lower in the population maintained on beta-blockers. ${ }^{14}$ In patients undergoing $\mathrm{CABG}$ surgery who received propranolol two hours preoperatively versus those in whom it was withdrawn 10-48 hours preoperatively, Oka et al. demonstrated a significantly lower heart rate-blood pressure product (RPP) both in response to intubation and at all other times during halothane- $\mathrm{N}_{2} \mathrm{O}$ anaesthesia. ${ }^{15}$

We have demonstrated that intravenous administration of a $50 \mu \mathrm{g} \cdot \mathrm{kg}^{-1}$ dose of fentanyl over 20 seconds is well tolerated and provides rapid induction of anaesthesia and stable haemodynamics during laryngoscopy and tracheal intubation in patients with coronary artery disease who are receiving beta-adrenergic receptor blockers. Before the technique used in this study can be recommended for general use in other patients under different conditions, it will have to be evaluated under a variety of clinical circumstances (e.g., hypovolemia, sepsis, poor ventricular function, varying degrees of beta-adrenergic receptor blockade). Whether vecuronium, one of the new generation of muscle relaxants reported to have lesser cardiovascular side-effects, ${ }^{16}$ might prove to be a superior relaxant in combination with high doses of fentanyl remains to be seen.

\section{References}

1 Scott JC, Stanski DR, Ponganis KV. Quantitation of fentanyl's effect on the brain using the EEG. Anesthesiology 1983; 59: A370.

2 Murkin JM, Moldenhauer CC, Hug CC Jr, Epstein $C M$. Absence of seizures during induction of anesthesia with high-dose fentanyl. Anesth Analg 1984; 63: 489-94.

3 Kentor ML, Schwalb AJ, Lieberman RW. Rapid high dose fentanyl induction for CABG. Anesthesiology 1980; 53: S95.

$4 \mathrm{Hug}$ CC Jr. Pharmacokinetics of drugs administered intravenously. Anesth Analg 1978; 57: 704-23.

$5 \mathrm{Hug} C \mathrm{C} \mathrm{Jr}$. Lipid solubility, pharmacokinetics, and the EEG: are you better off today than you were four years ago? Anesthesiology 1985; 62: 221-6.

6 Hess $R$, Herz A, Friedel K. Pharmacokinetics of fentanyl in rabbits in view of the importance for limiting the effect. J Pharmacol Exp Ther 1971; 179 474-84.
7 Sprigge JS, Wynands JE, Whalley DG et al. Fentanyl infusion anesthesia for aortocoronary bypass surgery: plasma levels and hemodynamic response. Anesth Analg 1982; 61: 972-8.

8 Lebowitz PW, Ramsey FM, Savarese JJ, Ali HH, DeBros FM. Combination of pancuronium and metocurine: neuromuscular and hemodynamic advantages over pancuronium alone. Anesth Analg 1981; 60: 12-7.

9 Brown EM, Krishnaprasad D, Smiler BG. Pancuronium for rapid induction technique for tracheal intubation. Can Anaesth Soc J 1979; 26: 489-91.

10 Reitan JA, Stengert KB, Wymore ML, Martucci RW. Central control of fentanyl-induced bradycardia during halothane anesthesia. Anesth Analg 1978; 57: $31-5$.

11 Saxena PR, Bonta IL. Mechanism of selective cardias vagolytic action of pancuronium bromide. Specific blockade of cardiac muscarinic receptors. Eur J Pharmacol 1970; 11: 332-41.

12 Sorensen $M$, Engback J, Viby-Mogensen J, Guldager $H$. Jensen $M$. Bradycardia and cardiac asystole following a single injection of suxamethanonium. Acta Anesthesiol Scand 1984; 28: 232-5.

13 McDonald $D H$, Zaiden JR. Hemodynamic effects of pancuronium and pancuronium plus metocurine in patients taking propranolol. Anesthesiology 1984; 60: $359-61$.

14 Stanley TH, DeLange S, Boscoe MJ, DeBruijn N. The influence of chronic preoperative propranolol therapy on cardiovascular dynamics and narcotic requirements during operation in patients with coronary artery disease. Can Anaesth Soc J 1982; 29: 319-24.

15 Oka Y, Frishman W, Becker RM et al. Clinical pharmacology of the new beta-adrenergic blocking drugs. Part 10. Beta-adrenoceptor blockade and coronary artery surgery. Am Heart J 1980; 99 : 255-69.

16 Morris RB, Cahaian MK, Miller RD, Wilkinson $P L$, Quasha AL, Robinson SL. The cardiovascular effects of vecuronium (ORG NC45) and pancuronjum in patients undergoing coronary arery bypass grafting. Anesthesiology 1983; 58: 438-40. 


\section{Résumé}

Neuf patients prémédiqués sous thérapie chronique aux bêta-bloquants et démontrant une bonne fonction ventriculaire sans atteinte valvulaire significative ou atteinte du tronc commun étaient investigués afin de déterminer leur réponse hémodynamique à l'induction rapide de l'anesthésie et l'intubation trachéale durant le pontage aortocoronarien électif. Du fentanyl $50 \mu \mathrm{g}^{\prime} \mathrm{kg}^{-1}$ et du pancuronium $0.15 \mathrm{mg} \cdot \mathrm{kg}^{-1}$ ont été administrés par voie intraveineuse en 20 secondes suivis 90 secondes plus tard par l'intubation trachéale. Cette séquence rapide d'induction anesthésique et d'intubation trachéale a été bien tolérée par tous les patients. Des changements statistiquement significatifs ont été détectés dans la fréquence cardiaque, la pression capillaire pulmonaire et la résistance vasculaire systémique. Cependant ces changements étaient minimes et considérés comme non cliniquement significatifs car aucun signe d'ischémie n'était détecté a l'électrocardiogramme. La présente étude démontre que de fortes doses de fentanyl étaient capables d'induire l'anesthésie rapidement et de protéger contre les changements hémodynamiques associés à l' intubation trachéale. 